\title{
Effects of different dietary fat sources on the fatty acid profile of backfat and intramuscular fat of pigs of various sire breeds
}

\author{
G. Flachowsky ${ }^{1,4}$, E. Schulz ${ }^{1}$, R. Kratz ${ }^{2}$ and P. Glodek ${ }^{3}$ \\ ${ }^{1}$ Institute of Animal Nutrition, Friedrich-Loeffler-Institute (FLI), \\ Federal Research Institute for Animal Health \\ Bundesallee 50, 38116 Braunschweig, Germany \\ ${ }^{2}$ Heinrich-Kreß-Straße 6, 63589 Linsengericht-Altenhaßlau, Germany \\ ${ }^{3}$ Institute of Animal Breeding and Genetics, Goettingen University \\ Albrecht-Thaer-Weg 3, 37075 Goettingen, Germany
}

(Received 26 March 2008; revised version 9 June 2008; accepted 24 June 2008)

\begin{abstract}
The aim of the feeding trial was to compare the effects of four different dietary fat supplementations ( $2.5 \%$ of tallow, olive oil, soyabean oil or linseed oil), three sire breeds and both sexes upon pig growth and usual carcass traits, but especially upon several meat and fat quality traits. Ninety-six weaners from different German and foreign sire breeds were tested for their ability to improve the quality of market products. The experiment was carried out with 48 barrows and 48 female growing/fattening pigs. They were progeny of German hybrid sows mated to Duroc, Hampshire $\times$ Duroc crosses or Pietrain $\times$ Hampshire crosses. The animals were individually kept from 30 to $120 \mathrm{~kg}$ liveweight.

Growth and slaughter performances of pigs were not significantly influenced by the supplemented fat source. The overall mean of intramuscular fat of loin reached only $1.3 \%$, varying between the sire breeds. The fatty-acid composition of backfat and intramuscular fat showed much smaller differences between sire breeds and sexes than between fat supplements to the diets. There were strong correlations between intake (x) and concentration of polyunsaturated fatty acids in backfat $\left(y=3.73 x-0.91 ; r^{2}=0.85\right)$. Similar correlations were calculated for oleic acid.

The results demonstrate that the fatty-acid profile in backfat and muscle can be substantially influenced by fat sources in the diet.
\end{abstract}

KEY WORDS: pig, fatty acid, backfat, muscle

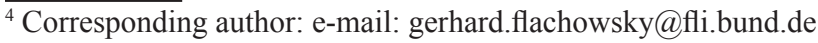




\section{INTRODUCTION}

In the last decades, superior genotypes in pig breeding have been selected almost only for growth parameters and carcass quality, with lean meat production as the major criterion. However, the decrease of fat in the carcass has been shown to be associated with a reduced intramuscular fat content, which is known to contribute substantially to meat quality factors such as juiciness and tenderness (Casteels et al., 1995; Fernandez et al., 1999), but recent studies by Rincker et al. (2008) did not show strong correlations between intramuscular fat content and eating quality. The optimal concentration is widely accepted to be in the range between 1.5 and $2.0 \%$ in the M. longissimus dorsi (Ender et al., 2001; Mörlein, 2007), but in modern genotypes, it is only 1\% (Biedermann et al., 2000; Warentest, 2002). Additionally, the fatty-acid profile contributes to carcass quality. Genetic construction of modern hybrids and feeding strategies are recognized as starting points for improvement. Apart from low intramuscular fat, the fatty-acid profile in backfat and muscle are also criticized because of the high proportion of saturated fatty acids. Therefore, animal breeders and animal nutritionists are asked to test the influence of breeding and nutrition on the fatty-acid profile of edible tissues. To address both parameters, a feeding experiment (Kratz, 2003) ending with carcass analysis was designed to study the effect of different fat sources in the diet on the performance of progeny from different sire lines, as well as on the transfer of dietary fatty acids into the backfat and intramuscular fat of pigs.

The objective of the present study is to report on the influence of four different fat sources on the fatty-acid profile of some body fat samples. Apart from the feeding, seasonal effects (Cava et al., 2000; Bee et al., 2004) and rearing systems (Patton et al., 2008) of pigs may also influence fat concentration and fatty-acid profiles in the body.

\section{MATERIAL AND METHODS}

\section{Experimental design}

The experiment was conducted with 48 castrated male and 48 female pigs. They were the progeny of German Hybrid sows mated to Duroc (Du), Hampshire $\times$ Duroc crosses $(\mathrm{Ha} \times \mathrm{Du})$ or Pietrain $\times$ Hampshire $(\mathrm{Pi} \times \mathrm{Ha})$ boars.

The animals were kept under individual feeding conditions. Feeding was restricted starting with $17 \mathrm{MJ}$ metabolizable energy (ME) per day at $30 \mathrm{~kg}$ liveweight (LW) and finishing with $38 \mathrm{MJ} \mathrm{ME}$ at $80 \mathrm{~kg} \mathrm{LW}$ to harmonize the feed and energy intake of animals of all groups. One standard diet was fed over the whole growing-finishing period from $30-120 \mathrm{~kg} \mathrm{LW}$ (Table 1). The dietary 
treatments were tallow, olive oil, soyabean oil, or linseed oil as the fat source, which was incorporated at a level of $2.5 \%$. The fat types were chosen for their fatty-acid profiles, with a predominance of saturated fatty acids - tallow, oleic acid - olive, linoleic acid - soyabean, or linolenic acid - linseed (Tables 1 and 2).

Table 1. Composition and feeding value of the experimental diets

\begin{tabular}{|c|c|c|c|c|}
\hline \multirow{2}{*}{$\begin{array}{l}\text { Feeds }(\%) \text { and } \\
\text { parameters of feeding value }\end{array}$} & \multicolumn{4}{|c|}{ Fat source } \\
\hline & tallow & olive & soyabean & linseed \\
\hline Wheat & \multicolumn{4}{|c|}{43.0} \\
\hline Barley & \multicolumn{4}{|c|}{32.0} \\
\hline Soyabean & \multicolumn{4}{|c|}{19.5} \\
\hline Fat & 2.5 & 2.5 & 2.5 & 2.5 \\
\hline Premix $^{1}$ & \multicolumn{4}{|c|}{3.0} \\
\hline $\mathrm{ME}^{2}, \mathrm{MJ} \mathrm{ME} / \mathrm{kg}$ & 13.54 & 13.62 & 13.68 & 13.61 \\
\hline Crude protein, $\mathrm{g} / \mathrm{kg}$ feed & 173 & 174 & 174 & 176 \\
\hline Lysine, g/MJ ME & 0.76 & 0.74 & 0.73 & 0.74 \\
\hline
\end{tabular}

${ }^{1}$ supplementation per kg complete feed, g: HCl-lysine 3.0, DL-methionine 0.5, threonine 0.5, $\mathrm{Ca} 7.5, \mathrm{P} 1.8, \mathrm{Na} 1.65, \mathrm{Na} 0.3$; IU: vit. A 12000, vit. $\mathrm{D}_{3}$ 1200; mg: vit. E 36, Cu 28.5, Zn 120, Mn 75, Fe 165, I 1.2, Se 0.3, cholinechloride 72 , vit. $\mathrm{B}_{1} 1.1$, vit. $\mathrm{B}_{2} 3$, vit. $\mathrm{B}_{6} 3$, vit. $\mathrm{K}_{3} 1.5$, niacine 15 , pantothenate $10, \mu \mathrm{g}:$ vit. $\mathrm{B}_{12} 22$

2 as determined in digestibility experiments

Table 2. Experimental design

\begin{tabular}{|c|c|c|c|c|}
\hline \multirow{2}{*}{ Diets } & \multicolumn{4}{|c|}{ Fat source } \\
\hline & tallow & olive & soyabean & linseed \\
\hline Dominating fatty acids ${ }^{1}$ & $\begin{array}{c}32 \% \text { palmitic } \\
18 \% \text { stearic }\end{array}$ & $73 \%$ oleic & $\begin{array}{l}53 \% \text { linoleic } \\
6 \% \text { linolenic }\end{array}$ & $\begin{array}{l}19 \% \text { linoleic } \\
53 \% \text { linolenic }\end{array}$ \\
\hline \multirow{2}{*}{$\begin{array}{l}\text { Animals } \\
\text { genotype }\end{array}$} & \multicolumn{4}{|c|}{ Progeny from sire line } \\
\hline & $\mathrm{DU}^{2}$ & \multicolumn{2}{|c|}{$\mathrm{DU} \times \mathrm{HA}^{3}$} & $\mathrm{PI}^{4} \times \mathrm{HA}^{4}$ \\
\hline Female (n) & 16 & \multicolumn{2}{|c|}{16} & 16 \\
\hline Barrows (n) & 16 & \multicolumn{2}{|c|}{16} & 16 \\
\hline Feeding & individual & & & \\
\hline Regime & restricted scale & & & \\
\hline Liveweight range & $30-120 \mathrm{~kg}$ & & & \\
\hline Slaughter investigations & as in official pro & ny testing & & \\
\hline
\end{tabular}

The energy value was determined in digestibility studies (Kratz, 2003), with the result that the ME-content did not differ substantially between the diets.

At the end of the experiment (120 kg body weight), all 96 pigs were slaughtered in the experimental slaughtering house of the Institute of Animal Nutrition of the FLI according to ALZ guidelines (ALZ, 1997). Samples were taken from the 
M. longissimus dorsi from the $14^{\text {th }}$ rib caudal, and backfat samples were taken from the same dorsal region. All samples were deep frozen $\left(-18^{\circ} \mathrm{C}\right)$ under vacuum until fatty acid analysis by gas chromatography.

\section{Analytical and statistical methods}

The official VDLUFA methods (1999) were applied to analyse the chemical composition and digestibility of the experimental diets, as well as the fat and fatty acids in the various tissues of the carcass. Data were subjected to variance analysis applying a 3-factorial design for the treatments "dietary fat source", "sire line" and "sex", using the GLM-package of SAS/SAT version 6.12. Mean $(\overline{\mathrm{x}})$ and standard deviation (SD) for all treatments are given.

More details on the feeding experiment, the slaughtering of pigs, sample taking and detailed analytical and statistical methods were described previously (Kratz, 2003; Glodek et al., 2004).

\section{RESULTS AND DISCUSSION}

The fattening and slaughtering results of pigs were not significantly influenced by fat sources (Kratz, 2003). The overall weight gain (30-120 kg BW) amounted to $870 \pm 47 \mathrm{~g}$ day $^{-1}, 35.1 \pm 2.1 \mathrm{MJ} \mathrm{ME} \mathrm{kg}{ }^{-1}$ weight gain were necessary.

The supplemented fats are characterized by specific fatty-acid profiles (Table 3). Tallow contains about $50 \%$ saturated fatty acids, olive oil nearly three-

Table 3. Important fatty acids of basal diet and supplemented fats, in percentage of determined fatty acids; $\mathrm{n}=4$

\begin{tabular}{lccccc}
\hline \multirow{2}{*}{ Fatty acids } & \multicolumn{5}{c}{ Fat source } \\
\cline { 2 - 6 } & basal diet & tallow & olive & soyabean & linseed \\
\hline Palmitic, $\mathrm{C}_{16: 0}$ & 18.5 & 31.7 & 12.0 & 25.0 & 6.1 \\
Stearic, $\mathrm{C}_{18: 0}$ & 1.8 & 17.8 & 1.8 & 2.1 & 2.2 \\
Oleic, $_{18: 1}$ & 18.9 & 37.7 & 72.8 & 21.6 & 17.2 \\
Linoleic, $_{18: 2}$ & 54.1 & 1.9 & 8.8 & 52.8 & 18.7 \\
Linolenic, $\mathrm{C}_{18: 3}$ & 5.6 & 0.4 & 0.8 & 5.9 & 52.6 \\
\hline
\end{tabular}

fourths oleic acid, and soyabean oil and linseed oil, about 60 and $72 \%$, respectively, of polyunsaturated fatty acids. The values are in agreement with some references showing the fatty-acid profile of fats in nutrition (Souci et al., 2000).

Due to the supplements of the different fat sources, which varied in their fattyacid profile, high concentrations of saturated, monounsaturated and polyunsaturated fatty acids were provided in the experimental diets (Table 4). 
Supplemented fat sources, sire line, and sex influenced the fatty-acid profile of backfat to different extents (Table 5).

Table 4. Important fatty acids (FA) in the experimental diets, $\mathrm{g} \mathrm{kg}^{-1}$ air dry matter; $88 \% \mathrm{DM}$

\begin{tabular}{lrrrr}
\hline \multirow{2}{*}{ Fatty acids } & \multicolumn{4}{c}{ Fat source } \\
\cline { 2 - 5 } & tallow & olive & soyabean & linseed \\
\hline Palmitic, C $_{16: 0}$ & 10.3 & 8.4 & 8.2 & 5.2 \\
Stearic, C $_{18: 0}$ & 3.9 & 0.8 & 0.9 & 0.8 \\
${\text { Oleic, } C_{18: 1}}_{\text {Linoleic, }_{18: 2}}^{11.6}$ & 18.6 & 8.9 & 7.6 \\
Linolenic, C & 11.9 & 13.3 & 21.8 & 15.3 \\
Saturated FA & 1.1 & 1.2 & 2.5 & 11.4 \\
Monounsaturated FA & 14.2 & 9.2 & 9.1 & 6.0 \\
Polyunsaturated FA & 11.6 & 18.6 & 8.9 & 7.6 \\
\hline
\end{tabular}

The supplemented fat sources showed significant effects on all fatty acids in the backfat. Higher concentrations of certain fatty acids in the feed (Table 4) resulted in higher proportions of specific fatty acids in backfat: supplementation of tallow significantly increased the concentration of saturated fatty acids in this tissue, olive oil resulted in significantly more oleic acid in depot fat, soyabean and linseed oils yielded the lowest content of oleic acid and significantly more polyunsaturated fatty acids, but showed large differences between linoleic and linolenic acids (Table 5).

Fattening pigs of the sire line $\mathrm{Pi} \times \mathrm{Ha}$ contained significantly more $(\mathrm{P}<0.05)$ palmitic and oleic acids and less polyunsaturated fatty acids than animals of sires $\mathrm{Du}$ and $\mathrm{Ha} \times \mathrm{Du}$. The difference is relatively small and its significance should not be overestimated. The results are in agreement with some studies (e.g., Honkavaara, 1989; García-Macías et al., 1996; Biedermann et al., 2000) in which small differences (0.2-1.9\% points) were also found in the fatty-acid profile of backfat depending on genotype. But the differences are not clearly directed and do not allow conclusions to be drawn.

The backfat of barrows contained significantly more $(\mathrm{P}<0.05)$ palmitic and less linoleic acids than those of gilts (Table 5). No significant differences were found for other fatty acids. Increased concentrations of saturated fatty acids in the backfat of barrows were also described by other authors (Van Oeckel et al., 1997; Warnants et al., 1999). It can be concluded from the results that a significant correlation exists between the intake of specific fatty acids and the fatty-acid profile in backfat in terms of some fatty acids. Regression analysis shows in detail that an additional intake of $1 \mathrm{~kg}$ polyenic fatty acids during the whole growing-finishing period results in an additional increase of 3.73 


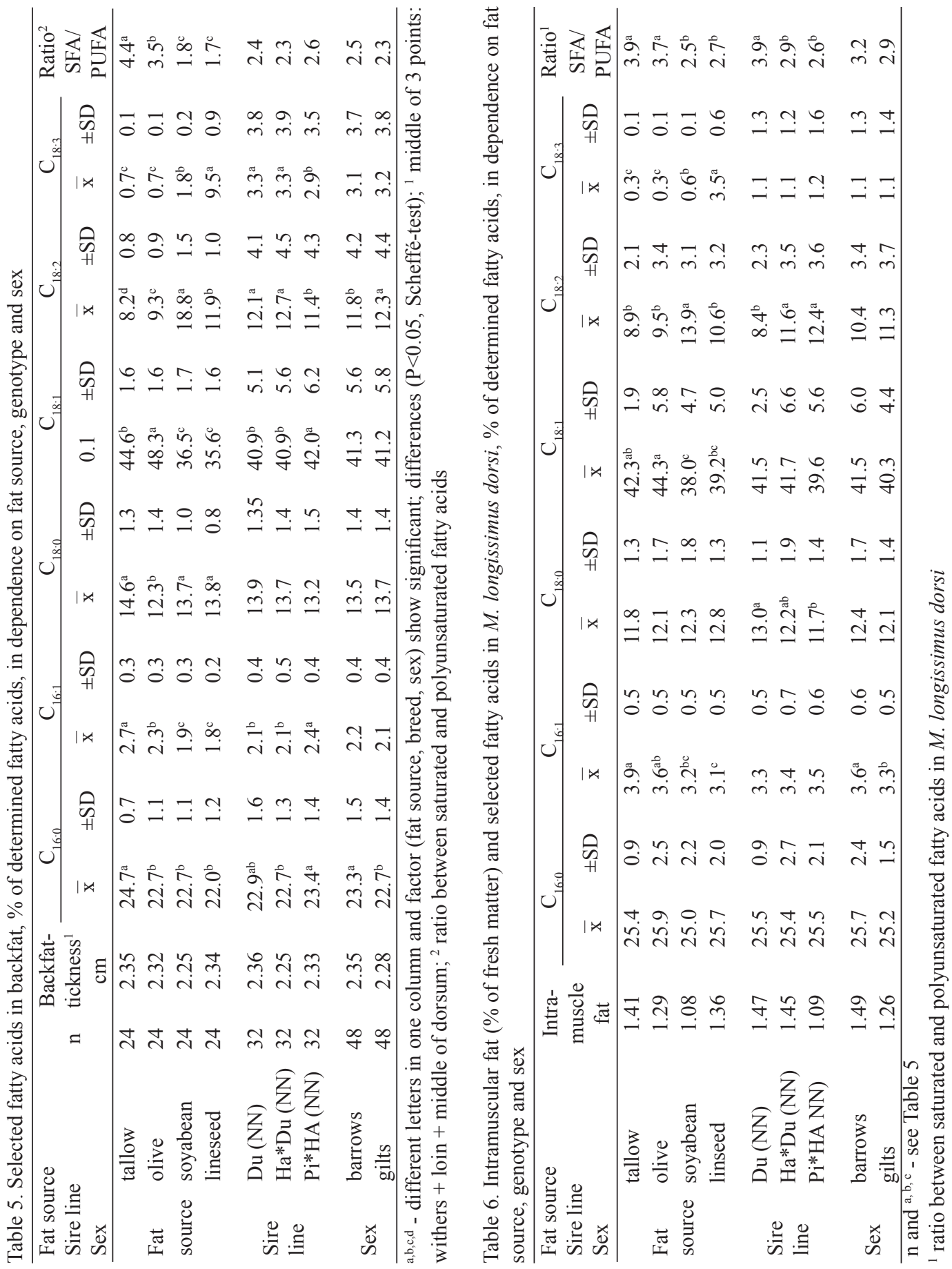


percentage points in backfat. The percentage of palmitic acid decreases slightly and that of stearic acid remains unaffected, whereas the oleic acid percentage decreases to almost the same extent as the polyenic acids increase (Figure 1).

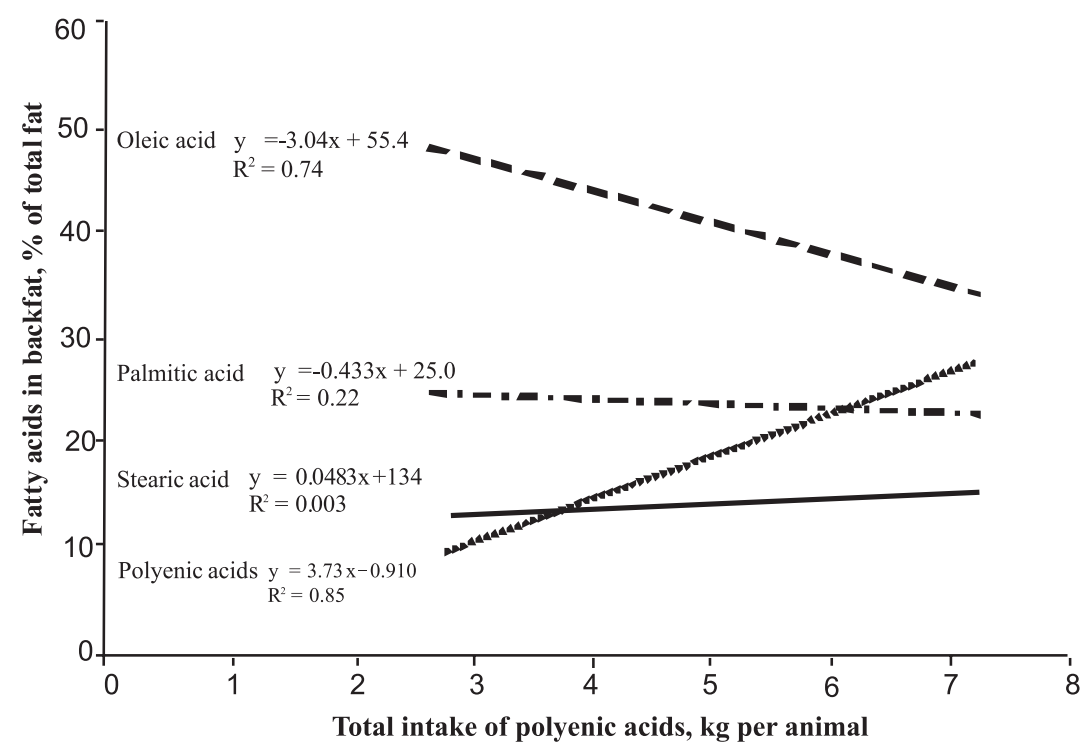

Figure 1. The fatty acids profile in backfat of slaughter pigs as related to the intake of polyenic fatty acids

One reason for the high transfer of added fatty acids could be the reduced de novo synthesis of fatty acids in the body if higher fat amounts are fed (Kijora et al., 1997; Kreuzer et al., 1997). Oleic acid in the depot fat came from oleic acid in feed and from stearic acid through the activity of stearoyl-CoA-desaturase in liver and fat tissue (Klingenberg et al., 1995).

Transfer of dietary fatty acids into the intramuscular fat was found, but not as distinctly as into backfat. The content of saturated fatty acids in M. longissimus dorsi remained unaffected. The mono- and polyenic fatty acids were influenced in the same direction as in backfat, but the effect was less pronounced (see Tables 5 and 6). The fatty acids in intramuscular fat are deposed more in cell membranes and the composition of the membranes is more stable than that of backfat, where fatty acids are found more in the cells. This means that the fatty acids dominating in the various dietary fat types are apparently deposited more in backfat than in muscular tissue. The percentage of polyenic fatty acids in the M. longissimus dorsi was also linearly correlated with their intake, but the coefficient of determination was found to be only $\mathrm{R}^{2}=0.32$. On average, an additional content of $1 \mathrm{~g}$ polyenic acids in $1 \mathrm{~kg}$ diet increased their concentration in the intramuscular fat by $0.43 \%$. 
Analysis of M. longissimus dorsi data for intramuscular fat showed a substantial effect of the sire line, although differences were not significant (Table 6). Using boars of Du or $\mathrm{Du} \times \mathrm{Ha}$, increased the intramuscular fat content by $0.37 \%$ as compared with Pietrain $\times$ Hampshire boars. This is in accordance with the observations of Glodek (1996) and Laube (2000). Small differences in IMF were also determined between sexes and in dependence on supplemented fat source. In all cases the IMF content of M. longissimus dorsi was below 2\% (Ender et al., 2001), which is considered to be a minimum requirement for good meat quality, juiciness and tenderness of muscle as demonstrated in some studies (Casteels et al., 1995; Fernandez et al., 1999). A significant effect of the sire line on the fatty-acid profile was detected, especially on the percentage of stearic and linoleic acids (Table 6).

Only small differences were found in the fatty-acid profile of M. longissimus dorsi between barrows and gilts (Table 6). The results are in agreement with findings by other authors (Van Oeckel et al., 1996; Warnants et al., 1999).

\section{CONCLUSIONS}

Different fat sources added to pig diets have a significant influence on the fatty-acid profile in the depot and intramuscular fat of pigs, in keeping with the fatty-acid profile of fat sources. The influence of the fatty-acid profile of fats fed to pigs is more pronounced in backfat than in intramuscular fat. The influence of genotypes and sexes of pigs on body fatty-acid profile is much lower than that of fat supplements. Further studies with more genotypes seem to be warranted to obtain high-quality meat products in fulfilling consumer expectations.

\section{REFERENCES}

ALZ, 1997. Richtlinie für die Stationsprüfung auf Wachstumsleistung, Schlachtkörperwert und Fleischbeschaffenheit beim Schwein. Ausschuss für Leistungsprüfungen und Zuchtwertfeststellung beim Schwein (ZDS)

Bee G., Guex G., Herzog W., 2004. Free-range rearing of pigs during the winter: adaptations in muscle fiber characteristics and effects on adipose tissue composition and meat quality traits. J. Anim. Sci. 82, 1206-1218

Biedermann G., Jatsch C., Peschke W., Lindner J.P., Wittmann W., 2000. Mast und Schlachtleistung sowie Fleisch- und Fettqualität von Piétrain-Schweinen unterschiedlichen MHS-Genotyps und Geschlechts. 1. Mitteilung: Fettsäurenmuster der Depotfette Rückenspeck, Flomen und intermuskuläres Fett sowie der Gesamt- und Phospholipide des M.long.dorsi. Arch. Tierzucht 43, 165-178

Casteels M., Van Oeckel M.J., Boschaerts L., Spincemaille G., Boucqué C.V., 1995. The relationship between carcass, meat and eating quality of three pig genotypes. Meat Sci. 40, 253-269

Cava R., Ventanas J., Ruiz J., Andres A., Antequera T., 2000. Sensory characteristics of Iberian ham: Influence of rearing system and muscle location. Food Sci. Technol.- Lebensm. Wiss. 6, 235-242 
Ender K., Kallweit E., 2001. Stellungnahme zum Thema: Intramuskulärer Fettgehalt im Schweinefleisch. Züchtungskunde 74, 245-246

Fernandez X., Monin G., Talmant A., Mourot J., Lebret B., 1999. Influence of intramuscular fat content on the quality of pig meat. 1 . Composition of the lipid fraction and sensory characteristics of m. longissimus lumborum. Meat Sci. 53, 59-65

García-Macías J.A., Oliver M.A., Diestre A., Alonso P., Muñoz-Luna A., Siggens K., CuthbertHeavens D., 1996. The effect of cross, slaughter weight and halothane genotype on leanness and meat and fat quality in pig carcasses. Anim. Sci. 63, 487-496

Glodek P., 1996. Die Wahl der Vaterlinie bestimmt die Qualität der Endprodukte in der Schweinezucht. Züchtungskunde 68, 483-492

Glodek P., Kratz R., Schulz E., Flachowsky G., 2004. Der Einfluss unterschiedlicher Vaterrassen in praxisüblichen Schweinekreuzungen auf deren Ansatzleistung, Schlachtkörperzusammensetzung sowie Fleisch- und Fettbeschaffenheit. Arch. Tierzucht 47, 59-74

Honkavaara M., 1989. Einfluss der Stressempfindlichkeit und Rasse von Schweinen auf die Fettsäurenprofile der subkutanen und intramuskulären Gesamtlipide. Fleischwirtschaft 69, 1484-1488

Kijora C., Kupsch R.D., Bergner H., Wenk C., Prabucki A.L., 1997. Vergleichende Untersuchung zum Einsatz von Glycerin, freien Fettsäuren, freien Fettsäuren und Glycerin sowie pflanzlichem Öl in der Schweinemast. J. Anim. Physiol. Anim. Nutr. 77, 127-138

Klingenberg I.L., Knabe D.A., Smith S.B., 1995. Lipid metabolism in pigs fed beef tallow or higholeic acid sunflower oil. Comp. Biochem. Physiol. Pt B 110, 183-192

Kratz R., 2003. Einfluss verschiedener Fettquellen in der Ernährung von Schweinen unterschiedlicher Genetik auf den Protein- und Lipidansatz, das Fettsäurenmuster verschiedener Teilstücke und die Fleischbeschaffenheit: Dissertation Justus-Liebig-Universität, Gießen (Germany), pp. 221

Kreuzer M., Gerdemann M.M., Reyer W., 1997. Selective improvement of porcine fat firmness by a diet enriched in medium-chain fatty acids. Fett-Lipid 99, 436-442

Laube S., 2000. Die Eignung spezieller Schweinekreuzungen zur Qualitäts-verbesserung von Markenschweinefleisch unter besonderer Berücksichtigung von MHS-Status, Hampshirefaktor und intramuskulärem Fettgehalt. Dissertation, Tierärztliche Hochschule, Hannover (Germany)

Mörlein D., 2007. Zerstörungsfreie Bestimmung des intramuskulären Fettgehaltes (IMF) im Kotelett von Schweinen mittels Ultraschall. Züchtungskunde 79, 81-91

Patton B.S., Huff-Lonergan E., Honeyman M.S., Kerr B.J., Lonergan S.M., 2008. Effects of space allocation within a deep-bedded finishing system on pigs growth performance, fatty acid composition and pork quality. Animal 2, 471-478

Rincker P.J., Killefer J., Ellis M., Brewer M.S., McKeith F.K., 2008. Intramuscular fat content has little influence on the eating quality of fresh pork loin chops. J. Anim. Sci. 86, 730-737

Souci S.W., Fachmann W., Kraut H., 2000. Food Composition and Nutrition Tables. Medpharm Science Publishers. Stuttgart, CRC Press, pp. 1181

Van Oeckel M.J., Casteels M., Warnants N., Boucqué C.V., 1997. Omega-3-fatty acids in pig nutrition: Implications for zootechnical performances, carcass and fat quality. Arch. Anim. Nutr. $50,31-42$

Van Oeckel M.J., Casteels M., Warnants N., Damme Lv., Boucqué C.V., 1996. Omega-3-fatty acids in pig nutrition: Implications for the intrinsic and sensory quality of the meat. Meat Sci. 44, 55-63

VDLUFA, 1999. Die chemische Untersuchung von Futtermitteln. Methodenbuch, Band III. C. Naumann, R. Bassler (Editors). Verband Deutscher Landwirtschaftlicher Untersuchungs-und Forschungsanstalten. VDLUFA-Verlag, Darmstadt

Warentest, 2002. Warentest für Mastferkel. Prüfungsbericht, Landw. Wbl. Westfalen-Lippe, Münster

Warnants N., Van Oeckel M.J., Boucqué C.V., 1999. Incorporation of dietary polyunsaturated fatty acids into pork fatty tissues. J. Anim. Sci. 77, 2478-2490 